\title{
An Analysis of Quantitative Credit Controls and Related Devices
}

QUANTITATIVE CONTROLS ON SUPPLIERS AND USERS of credit have for some time been a notable feature of policies designed to moderate aggregate demand and, at times, to influence its distribution in a number of developed countries. In the United States, a fairly comprehensive system of voluntary credit controls was in effect for a time during the Korean war, and quantitative controls were again advocated by some to alleviate the tight financial markets of the late 1960s. Indeed, a law passed by Congress in 1969 included a provision, opposed by both the administration and the Federal Reserve, permitting the President to authorize the Federal Reserve Board "to regulate and control any or all extensions of credit" whenever he determines that such action is "necessary or appropriate for the purpose of preventing or controlling inflation. ..."1

While public discussion of credit controls seems to have waned with the restoration of easier conditions in financial markets, an examination of their economic consequences appears worthwhile for at least three reasons. First, in the nature of things, a bout of financial stringency is certain to

* I wish to acknowledge helpful discussions with Marcel Arak, Frederick Schadrak, and Albert Wojnilower, besides help from participants on the Brookings panel. The views expressed in this paper are the responsibility solely of the author and do not necessarily reflect the views of the Federal Reserve Bank of New York.

1. Public Law 91-151, Title II, Section 205 (a) (83 Stat. 377). 
recur some day and the advocacy of credit controls as an anti-inflationary device is likely to recur with it. Second, credit controls as applied to banks share some features with other devices recently employed in this country, such as Regulation $\mathrm{Q}$, which places ceilings on the interest rates banks may pay on time and savings deposits. Third, some proponents of credit controls favor them mainly as a means of influencing the composition of aggregate demand rather than as a technique for restraining its total. As a result, such controls may remain a relevant subject for analysis even in times of relatively easy credit.

A major reason for the use of quantitative controls over bank credit in some foreign economies has apparently been the feeling that more "orthodox" monetary tools such as reserve requirements and open market operations are, for various technical reasons, inadequate significantly to restrain aggregate demand. Whatever the validity of such arguments as applied to these countries, they are manifestly irrelevant to the U.S. situation. The Federal Reserve plainly has the means to restrain the growth of the major monetary aggregates and, after the experience of 1966 and 1969-70, the ability of monetary policy to restrain aggregate demand has ceased to be a live issue.

While the potency of monetary policy is no longer seriously questioned, there undoubtedly remains some dissatisfaction with the manner in which general monetary restraint operates, and credit controls are sometimes mentioned as possible remedies. For one thing, general policies of monetary restraint require time to produce their effects on aggregate demand. Estimates of the lags vary, and the explanations offered for their existence depend on the relative significance attributed to various avenues of monetary influence. Those who emphasize the effects of credit availability, especially bank credit availability, often point out that banks react initially to a tight money policy by selling securities and, perhaps, by selling interestbearing time certificates of deposit (CDs); as was evident in 1966 and again in 1969, these actions enabled banks to postpone the adoption of tighter lending policies. On this view, quantitative credit controls (or the early imposition of interest rate ceilings under Regulation Q) would speed credit rationing and increases in interest rates on bank lending and in this way would speed the response of aggregate demand.

A second objection to general monetary restraint is the upward pressure that it exerts, at least in the short to medium run, on interest rates. Due to a variety of factors, including institutional rigidities, rises in interest rates 
can have sharp and perhaps undesirable effects on the relative positions of financial institutions, on the allocation of credit, and on the income and balance sheet positions of vulnerable institutions. If, by rationing some credit claimants out of the market by fiat, the same restraint on aggregate demand could be achieved with smaller rises in interest rates, these undesirable side effects of general monetary tightening might, it is argued, be lessened.

A closely related objection often raised to policies of general monetary restraint is that they bear unequally, perhaps in socially undesirable ways, on different sectors of the economy. In particular, housing reacts quickly and sharply to credit restraint. Similarly, state and local government finance may be especially sensitive to general monetary restraint because of the heavy dependence of the market for tax-exempt bonds on banks, coupled with the tendency of banks to favor business borrowers in periods of restraint. Another frequently mentioned complaint is that general monetary restraint discriminates against small business borrowers who are much less likely than larger firms to have significant alternative sources of funds when the availability of bank loans finally begins to be curtailed. In short, among the major spending units, large corporations are least vulnerable to monetary restraint. Hence interest rates may have to be driven up substantially, putting equally or perhaps more deserving economic sectors under severe strain before corporate borrowers are significantly inhibited. It is sometimes suggested that these various allocational properties of general tight money might be altered by a proper assortment of quantitative credit controls.

This paper attempts to analyze the impact of certain types of credit controls on the level and distribution of aggregate demand, on flows of funds, and on interest rates under the assumption of a given "monetary policy." As a matter of analytical clarity, the impact of quantitative credit controls can be compared with the noncontrol situation only if some target of general monetary instruments is assumed to be "the same" both with and without the controls. There are any number of "unchanged" monetary targets that could be chosen. Thus it could be assumed that the level (or rate of growth) of reserves, the narrow or broad money supply, or the level of one or more interest rates is kept the same in the controls as in the no-controls situation. For present purposes, it is most convenient to assume that the time path of the narrowly defined money supply (currency plus demand deposits-hereafter called simply the money supply) is the 
same with controls and in their absence. This approach makes it possible to concentrate on the pure "credit" effects of both direct and indirect controls on bank credit, and as a side benefit, to illuminate the relationship between bank credit and the money supply as partially alternative and competing "indicators" of the tightness or ease of monetary policy. A major limitation of the paper is that it does not provide quantitative estimates of the effects of controls, although some qualitative judgments of the magnitudes involved are offered. In the absence of suitable econometric models and of relevant experience with such controls in this country, provision of such quantitative estimates would have been an infeasibly largeconceivably even an impossible-undertaking.

Many critical considerations beyond the purely economic consequences of controls traced out in this paper would have to be examined before one could recommend for or against any particular control device. All administrative controls, including those on credit, interfere with the market's allocation of goods and services, profits and incomes. While some of these interferences may be the deliberate aim of controls, they may well prove to have other effects that are not desired. Similarly, all administrative controls involve some bureaucratic machinery. In the present case there would undoubtedly be problems in making adjustments to the special circumstances of certain borrowers or classes of borrowers. Base periods would have to be established from which permitted credit expansions could be calculated. In certain situations, "announcement effects" might be expected, as borrowers rushed to get accommodated under the newly promulgated ceilings. An additional problem is that all controls tend to generate evasion, both in the narrow sense that the rules may be evaded and in the larger sense that, given time, the market tends to generate alternatives to the channels dammed up by controls. These factors tend to lead to a proliferation of controls and so on. Major questions arise: Would the potential desirable effects of controls offset these various liabilities? Would alternatives such as tax and subsidy schemes, federal loan guarantees, or direct federal lending achieve the desirable effects more satisfactorily? As the recent agony over incomes policy suggests, questions of this general sort cannot be answered in the abstract; they must be examined in the context of a specific political environment.

It should also be noted that the analysis of this paper rests on the proposition that changes in the relative supplies of various financial instruments, whether induced by the direct imposition of credit controls or by other 
devices, affect the composition of output only because financial specialization makes certain categories of spending especially sensitive to developments in the markets for specific financial instruments. For example, it is reasonable to assume that any device that causes financial intermediaries to shift out of corporate bonds and into mortgages will tend to shift relative rates on these instruments and thereby induce a shift out of plant and equipment investment and into housing. If spending units could finance outlays of any type as easily through mortgage issues as through bond flotations, or if the various kinds of financial and physical assets were near-perfect substitutes in the portfolios of nonfinancial units, such shifts in the composition of output might not take place. But it is a pervasive fact of financial life that various modes of finance tend to be specialized to particular types of outlays. Real investment by business and households in the types of physical capital most characteristic of each sector is far more sensitive to interest rates on the financial instruments "specialized" to these activities than it is to yields on financial assets linked to other categories of spending. ${ }^{2}$

This paper will consider the following kinds of credit controls: (1) quantitative limits on total bank credit, but not on the composition of bank credit (the impact of Regulation Q and like devices is also reexamined in this section); (2) quantitative limits on specific components of bank credit such as loans to business, finance companies, and consumers, but not on the total; and (3) quantitative limits on effective demand for credit-specifically, controls over corporate capital issues.

\section{Effects of Devices Limiting Total Bank Credit}

Quantitative ceilings on total bank credit are probably of particular interest in financial systems where orthodox central bank instruments are not adequate tools for controlling such credit. The Federal Reserve, however, can fix total bank credit or any other single banking and monetary aggregate at any desired magnitude, at least to a crude approximation, through its control over nonborrowed reserves. To do this, it must of course take rough account of relevant developments in the banking system that are not under its direct control (such as the time-demand deposit mix, the public's currency-deposit ratio, and so forth).

2. I have profited from a rigorous treatment by D. C. Rao and Ira Kaminow of the elasticity conditions necessary for shifts in intermediary demand schedules for particular financial instruments to have an influence on the composition of real output. 
While the Federal Reserve can theoretically set nonborrowed reserves at whatever level is needed to induce the banking system to provide roughly the target amount of total bank credit, a direct quantitative control might nevertheless be considered desirable for three reasons. First, to hit the bank credit target with the desired degree of accuracy requires correct allowance for the offsetting items; this may be difficult to achieve. Second, the Federal Reserve might wish to hit the target level of bank credit more quickly than is considered feasible with conventional tools. Third, if the Federal Reserve wishes to control independently the magnitudes of two different monetary variables, such as bank credit and the money supply, it must have an instrument beyond those of general reserve control. To be sure, the additional instrument need not be something as blunt as the power to set a quantitative bank credit quota. It could instead be some device such as Regulation $\mathrm{Q}$ that operates on nondemand deposit liabilities and therefore drives a wedge between money supply behavior and bank credit behavior. Indeed, as there will be occasion to emphasize at several points, Regulation $\mathrm{Q}$ and similar controls share a number of analytical features with direct controls on total bank credit.

\section{BANKING SYSTEM EFFECTS}

The effects of a bank credit control, for a given money supply target, on bank reserves, deposits, and credit must be clarified as a first step toward the analysis of its effects on the economy. If, for simplicity, a constant currency-demand deposit ratio is assumed, the assumption that the money supply target is the same whether or not bank credit controls are imposed also implies that the target level of demand deposits must be the same with and without controls. The situation of the banking system with and without controls, assuming the given demand deposit target is achieved in both instances, can be illustrated with the following hypothetical consolidated balance sheet:

\section{Without controls}

\begin{tabular}{|c|c|c|c|}
\hline Reserves & 30 & Demand deposits & 100 \\
\hline Bank credit & 220 & $\begin{array}{l}\text { Other liabilities } \\
\text { (Time deposits 100) } \\
\text { (Nondeposit } \\
\text { liabilities 50) }\end{array}$ & 150 \\
\hline & 250 & & 250 \\
\hline
\end{tabular}


With controls

\begin{tabular}{|c|c|c|c|}
\hline Reserves & 30 & Demand deposits & 100 \\
\hline Bank credit & 200 & $\begin{array}{l}\text { Other liabilities } \\
\text { (Time deposits?) } \\
\text { (Nondeposit liabilities?) }\end{array}$ & 130 \\
\hline
\end{tabular}

As this balance sheet makes clear, if the Federal Reserve does successfully hold the level of demand deposits to its unchanged target and if the imposition of controls does lower total bank credit, then, simply as a matter of accounting, downward adjustments must take place in the nondemand deposit liabilities of the banking system. As media of short-run adjustments, the most important of the liabilities are clearly time deposits and the nondeposit short-term interest-bearing liabilities. In the most recent tight money period, the latter consisted mainly of head office borrowings (through overseas branches) of Eurodollars and commercial paper issued by holding companies of commercial banks. ${ }^{3}$

How would banks in fact react to the imposition of a quantitative limitation on bank credit? Would the money supply and demand deposits remain unchanged at their targeted levels without Federal Reserve intervention, or would action by the Federal Reserve be required? Would it be technically feasible for the Federal Reserve to engineer an increase in the money supply along a given target growth path while restricting bank credit through quantitative controls?

Banks faced with the necessity of reducing loans and investments to meet a bank credit quota could, in theory, use the proceeds of security sales and loan repayments to build up excess reserves. As long as banks have interest-bearing liabilities outstanding, however, they seem far more likely to use these proceeds to repay expensive Eurodollar borrowings and to allow a runoff in $\mathrm{CD}$ and other time and savings deposit liabilities. The latter would be accomplished in part by simply refusing to renew some types of maturing deposits, but presumably it would be brought about mainly through the effect of reduced interest yields on the public's desire to hold these deposits. In any case, a runoff of time deposits would liberate

3. Whether declines in this bank-related commercial paper could serve as a counterpart on the liability side to bank credit reductions would depend upon whether the credit restrictions were applied narrowly to commercial banks or, more broadly, to the holding companies. 
excess reserves at individual banks and in the banking system as a whole. To the extent that these excess reserves could be redistributed through the federal funds market to banks still under their credit limits, they would provide the potential for demand deposit expansion. To this extent, therefore, the conventional instruments would be needed to mop up the excess reserves in conformity with the unchanged money supply target.

The following balance sheets (1) and (2) illustrate, respectively, the position of commercial banks before and after both the imposition of the credit ceiling and the related action of the Federal Reserve to mop up excess reserves. In the example, the new credit ceiling is assumed to be 155; reserve requirements against demand and time deposits are assumed to be 20 percent and 5 percent, respectively; and the bank demand for excess reserves is assumed to be zero both "before" and "after." In this illustration, bank reserves decline by 1.1 , reflecting an open market sale by the Federal Reserve of the same amount.

(1)

\begin{tabular}{lrll}
\hline Required reserves & 25 & Demand deposits & 100 \\
Excess reserves & 0 & Time deposits & 100 \\
Bank credit & $\underline{175}$ & & \\
& 200 & & 200
\end{tabular}

(2)

\begin{tabular}{lrlr}
\hline Required reserves & 23.9 & Demand deposits & 100.0 \\
Excess reserves & 0.0 & Time deposits & 78.9 \\
Bank credit & 155.0 & & \\
& $\overline{178.9}$ & & 178.9
\end{tabular}

The task of expanding the money supply along a targeted growth path at a time when bank credit expansion was being constrained by an officially imposed ceiling would create some rather novel problems for the central bank. In particular, the existence of the bank credit ceiling would inhibitalthough not preclude - the use of the orthodox instruments to promote monetary expansion. The Federal Reserve could still engage in expansionary open market purchases. However, the excess reserves created in the process could not be used for further deposit expansion, since any such expansion could be set in motion only by increased bank lending and investing in violation of the credit ceiling. This means, in effect, that the Federal Reserve would be able to expand deposits only one dollar for each 
dollar of reserve expansion. ${ }^{4}$ No "multiple expansion" of deposits would be possible. Whenever the bank credit quota was raised or lifted altogether, moreover, increases in reserve requirements or massive open market sales would probably be needed to prevent an avalanche of new deposits and credit arising from previously sterilized excess reserves or from any other distortions the ceiling might have produced.

\section{EFFECTS ON AGGREGATE DEMAND}

The effects of bank credit ceilings on aggregate demand, given the money supply, cannot be determined on an a priori basis alone. The outcome depends on which assets the banks reduce, on which nondemand deposit liabilities are allowed to decline, on the instruments in which former holders of these liabilities choose to reinvest their funds, and on the relative elasticities of the various sectors of aggregate demand with respect to interest rates on the various financial instruments. The range of theoretically possible outcomes can be illustrated by a few hypothetical situations. ${ }^{5}$

1. Suppose the commercial banks concentrate the reduction in credit in mortgage lending, allowing savings deposits to run off (presumably by lowering interest rates). Assume further that holders of these deposits reinvest in savings and loan shares and that the savings associations increase their mortgage lending accordingly. In this case there would probably be

4. By assumption, bank credit would not expand at all with the expansion of the money supply. However, the open market purchases of the Federal Reserve required to increase the money supply would mean an increase in Federal Reserve credit. In the absence of any changes in time deposits, Federal Reserve credit would have to rise by the amount of the targeted increase in the money supply.

5. The analysis of the next several paragraphs leans heavily on the formal model developed by James Tobin in "Deposit Interest Ceilings as a Monetary Control," Journal of Money, Credit and Banking, Vol. 2 (February 1970), esp. pp. 11-14. To be relevant to the present case, the Tobin model must be reformulated slightly, replacing his assumption that nonborrowed reserves are fixed by policy with the assumption that the equilibrium value of demand deposits is made to conform with a policy target, with the central bank supplying whatever volume of nonborrowed reserves is needed to achieve this objective. This transformation renders irrelevant what Tobin calls the "reserve effect" of changes in such liabilities as time deposits. In addition, the Tobin model would have to be modified to allow for more than one type of private real capital, for more than one type of private financial instrument, and for the existence of credit rationing. Readers of the Tobin paper will recognize that the next several paragraphs of the present paper deal largely with the question of the probable sign, in a multisector, multifinancial-instrument context, of what Tobin calls the "asset swap" effect. 
little or no effect on the level or composition of aggregate demand. The credit ceiling would act mainly to shift the competitive balance (and the flow of mortgage lending) against the commercial banks and in favor of the competing savings institutions.

2. Assume the same as above, except that this time the commercial banks meet their total bank credit quota by selling off U.S. government securities rather than mortgages. In this case there would be a net increase in the demand for mortgages and a net decline in the demand for U.S. government securities. Mortgage rates would tend to fall and rates on Treasury securities to rise. Although one cannot be absolutely sure a priori, it is certainly reasonable to assume that aggregate demand would actually be stimulated by the imposition of bank credit ceilings in this case since housing outlays are quite sensitive to mortgage rates and availability, while federal spending is not sensitive to Treasury borrowing costs.

3. Again consider the general situation posited in the previous two cases, with banks this time reducing holdings of state and local government securities. As before, the demand for mortgages would rise and, as a result, mortgage rates would tend to fall. At the same time, however, the market demand for tax-exempts would fall and rates on these securities would tend to rise. The net effect on aggregate demand would depend largely upon the relative elasticities of spending on housing and on state and local government activities to interest rates on the respective instruments normally used to finance them.

4. Assume this time that commercial banks cut back primarily on lending to business and consumers. Suppose the banks offset these cutbacks on the liability side by allowing large CDs to run down and that former holders of these instruments attempt to reinvest their funds in Treasury bills. In this case it seems fairly clear-though again not absolutely certain a priori-that aggregate demand would be depressed.

5. Assume banks cut back on business lending, and allow large CDs to run off, and, further, that former investors in CDs attempt to reinvest their funds in business paper such as commercial paper. For the moment, assume that all business borrowers have access to the commercial paper market and are indifferent as to whether they borrow in this market or from banks. Assume further that investors are indifferent between holding interest-bearing bank liabilities and commercial paper at the preexisting rate structure. In this set of circumstances, there would be no net effect on aggregate demand. Business borrowing previously arranged through 
the banking system will now be undertaken directly in the open market with no change in commercial paper rates.

Given the welter of conceivable outcomes suggested by these five examples, it is clear that the effect of a bank credit ceiling on the level of aggregate demand can, theoretically at least, be anything at all. Nevertheless, it seems reasonably clear that such ceilings would in practice prove to be depressing on balance. The most favorable possibility for aggregate demand is that nonbank investors might prove indifferent between interest-bearing bank liabilities and paper issued by the nonbank nonfinancial sectors and these sectors, in turn, might be indifferent between borrowing from banks and borrowing directly through the market. Barring sectoral distribution effects, the impact of a bank credit ceiling on aggregate demand in this case would be essentially a standoff. Its main effect would be merely to reduce credit extension through the banks acting as intermediaries and to increase credit extended directly through the market or through nonbank intermediaries. The nonbank channels of credit, being perfect substitutes for the bank channel, would provide a frictionless substitute and, again barring distribution effects, there would be no effect on aggregate demand or on the general level of interest rates.

In fact, however, nonbank investors would not be indifferent between holding interest-bearing bank liabilities and other market paper, nor would nonfinancial borrowers be indifferent between borrowing from banks and from nonbank channels. Indeed, the preferences of these two groups would work in the direction of depressing aggregate demand should a bank credit ceiling be imposed. On the one hand, former holders of time deposits may not be willing to shift their funds, dollar for dollar, into nonbank paper at its existing interest rate. To some extent, at least, they may prefer demand deposit balances. Much more to the point, however, nonfinancial units that formerly borrowed from banks are most unlikely to be willing or able to shift to nonbank sources of funds, dollar for dollar, at the existing interest rates. This reluctance is, indeed, the strongest single reason for believing that a bank credit ceiling would, on balance, depress aggregate demand.

A number of factors would help make nonbank alternative credit a lessthan-perfect substitute for bank loans. First, some small business and consumer borrowers are unlikely to be able to substitute fully nonbank credit or other financial sources for the now unavailable bank credit. Second, since, in the absence of controls, bank borrowings were "revealed 
preferred" to other forms of finance, one must assume that, at the existing set of interest rates, the nonbank alternatives are regarded by borrowers as inferior in terms of transactions costs, portfolio balance, or convenience considerations. Thus, for example, while a large firm may be able to enter the commercial paper market to replace cutbacks in bank loans, it will face set-up costs. Moreover, the liquidity position of the firm will be weaker since, as events in 1970 dramatically demonstrated, the firm cannot count absolutely on rolling over commercial paper as needed, especially if bank back-up lines are not available. Smaller, lesser-known firms may not be able to sell either long- or short-term capital market instruments at all and may have to turn to commercial factors or depend more heavily on trade credit from suppliers. But credit from factors is less reliable than a line of bank credit and is likely to be more expensive. Trade credit is probably also more expensive in monetary terms and may weaken the borrower's position vis-à-vis his supplier with respect to all sorts of nonprice terms of trade. Finally, the would-be borrower may sell short-term financial assets, if he has them, to substitute for the unavailable bank loans. But this, too, entails obvious risks in the form of reduced liquidity. Thus, while all sorts of potential substitutes for bank borrowing are available, none of them will be a perfect substitute. Therefore, there will be at least some cuts in total credit flows and in spending on output by businesses and consumers whose access to bank borrowing has been reduced. ${ }^{6}$

To be sure, the distribution effects could turn out to be expansionary on balance as examples (2) and, possibly, (3) outlined above illustrate. They would be most likely to be expansionary if the net effect of the redistribution of flows through the various credit channels were to increase substantially the fraction of funds flowing into housing finance-since, to all appearances, housing is the most interest-sensitive demand sector. There

6. The argument can be put in supply-demand terms as follows: Suppose the credit ceiling reduces bank credit by 100 and that the banks allow an equal volume of time deposits to run off. Even if lenders are indifferent between time deposits and other open market paper, the supply curve of funds extended through such paper will shift out by no more than 100. If borrowers do not regard open market borrowing as a perfect substitute for bank borrowing, or if some borrowers simply do not have access to open market borrowing, the demand schedule for funds borrowed in the open market will shift out by something less than 100 . The result will be a fall in the open market rate. Credit extended in this market will rise, but by less than 100 . Consequently, total credit extended to nonfinancial borrowers (bank credit plus open market credit) will fall. It is easy to show further that spending by these sectors will also fall, given conventional assumptions. 
seems to be no particular reason to expect such an increase in the share of mortgage funds, however-or at least no reason unless the cutback in bank interest-bearing liabilities bears relatively most heavily on savings deposits and on other consumer-type deposits that are close substitutes for the liabilities of the specialized mortgage lending institutions. Such an eventuality does not seem likely. On the contrary, especially in a tight money period, the commercial banks would appear more likely to cut back relatively most heavily on high-cost liabilities in the money market, such as large CDs and Eurodollar borrowings. Moreover, even if the cutbacks were mainly in savings deposits, with a resulting shift of funds to the nonbank savings institutions and a stimulus to housing, there is still no guarantee that the distribution effect on aggregate demand would be positive on balance. One would also have to know what earning assets were reduced by the banks in response to the credit ceiling.

To summarize, some bank borrowers do not have access to important nonbank sources of credit. Moreover, borrowers in general will, for a variety of reasons, be unwilling to shift their borrowings, dollar for dollar, to nonbank sources at their existing interest rates. Thus the consequence of restrictions on total bank credit will be some reduction in both total credit flows and aggregate demand. In theory, a redistribution of credit that favored sectors that are highly sensitive to credit market conditions could offset the general tendency for aggregate demand to decline. Despite this possibility, the net overall effect is in fact virtually certain to be downward. ${ }^{7}$

\section{REGULATION Q AND AGGREGATE DEMAND}

The above analysis of the impact of controls on total bank credit essentially applies also to Regulation $\mathrm{Q}$ and similar devices that tend to restrict the volume of nondemand deposit bank liabilities. In the bank credit control case, ceilings are put on bank credit and the banks are thus

7. It is somewhat tempting to argue the case in familiar IS-LM terms. On this interpretation, the imposition of bank credit ceilings in the face of less-than-perfect nonbank alternatives shifts the IS curve to the left at any given level of "the" interest rate. Given the money supply, by assumption fixed at the policy target, and assuming no shift in the liquidity preference schedule at given levels of "the" interest rate, the equilibrium values of both aggregate demand and the interest rate would fall. However, since a multiplicity of financial markets, demand sectors, and interest rates is an essential feature of this problem, the IS-LM framework with its single interest rate is a clumsy device. Thus, while the "average" (in some sense) level of interest rates might fall in response to a bank credit ceiling, some particular interest rates could certainly rise. 
induced to lower offering rates on time deposits and other interest-bearing liabilities. In the Regulation $Q$ case, these offering rates are reduced by fiat and the banks are induced to cut back supplies of loans and investments. Perhaps the most significant difference between the two approaches, in terms of their effects on aggregate demand, is that Regulation $Q$ can be "fine-tuned" to bear on particular classes of bank interest-bearing liabilities as desired, while in the bank credit control case the banks themselves determine what interest-bearing liabilities will be reduced and in what proportion. The precise nature of the reduction in liabilities is significant because it influences the likely reinvestment demand by former holders of these liabilities, thereby influencing, in turn, the direction and magnitude of the "distribution effect" noted earlier.

If, for example, the Regulation $\mathrm{Q}$ ceiling is restricted to savings deposits and consumer-type time deposits at commercial banks alone, reinvestment will probably be heavily weighted toward mutual savings bank deposits and savings and loan shares. This is the case most likely to have a positive distribution effect by tending to increase the proportion of credit flows moving into mortgages. By the same token, it is the case least likely to have a significant depressing effect on aggregate demand. Indeed, the overall effect on demand could conceivably be neutral or even positive on balance.

In recent years, of course, ceilings on interest rates on savings deposits have been applied not only to commercial banks, but to mutual savings banks and savings and loan associations as well. This approach, especially in view of the adjustment of ceiling rates to reflect the previous patterns of institutional differentials, has greatly reduced any effect the ceilings might otherwise have had on the competitive balance between commercial banks and the two other types of institutions. In this situation, it is not entirely clear what effect the ceilings on savings deposit interest rates may have had on the proportion of funds moving into housing. James Tobin and Milton Friedman, who have analyzed this problem, seem to agree that across-the-board rate ceilings on savings-type deposits may well curtail, on balance, the supply of funds to housing by reducing the flow of funds to all the institutions offering such deposits, taken as a group, including the intermediaries specializing in mortgage lending. ${ }^{8}$ Their

8. James Tobin, "Deposit Interest Ceilings as a Monetary Control," and Milton Friedman, "Controls on Interest Rates Paid by Banks," Journal of Money, Credit and Banking, Vol. 2 (February 1970), pp. 8-11 and 28-29, respectively. 
argument assumes, however, that the ceilings are not needed to prevent a wholesale collapse of the specialized lending institutions from an earnings squeeze that might, in the absence of deposit rate ceilings, be precipitated by sharp rises in open market rates. ${ }^{9}$

The application of Regulation Q ceilings to large CDs (and of reserve requirements to bank-related commercial paper and to Eurodollar borrowings) have had, so far as can be discerned, no "distribution effects" on credit flows that have been stimulative to aggregate demand. Moreover, the unavailability or relative unattractiveness (at existing rates) of nonbank sources of funds exerts its full demand-depressing force in this case. On balance, it seems reasonable to conclude that Regulation $Q$ ceilings, at least as they have been administered in recent tight money periods, have tended to reduce the level of aggregate demand relative to what it otherwise would have been, given the money supply. The size of this effect would, of course, be useful knowledge, but there seems to be no reasonable way to estimate it. ${ }^{10}$

\section{REGULATION Q AND THE MONETARY INDICATOR PROBLEM}

This analysis of the effects of Regulation $Q$ on credit and aggregate demand has some bearing on issues raised in recent years about the com-

9. Tobin argues that the drain on savings and loan earnings that would, in the absence of rate ceilings, have resulted during the 1966-69 period could have been met simply by reductions in the earned surplus these institutions as a group had built up in earlier years. However, this view is based on a study of aggregate industry data and gives no weight to the shaky liquidity and earnings position of individual institutions and the potential for general runs that might have been created by a few well-publicized failures.

10. It may be of some interest to note the pattern of errors in "reduced form" equations relating current changes in the gross national product to current and past changes in the narrow money stock during the most recent tight money period (roughly early 1969 through early 1970), a period during which Regulation $Q$ acted as a binding constraint on time deposit rates. During the four-quarter period beginning with the third quarter of 1969 (a reasonable starting point given the lag structures of the equations), these money supply equations (estimated on data from 1952:2 to 1968:2) show a clear-cut tendency to overpredict quarterly increases in GNP-though, to be sure, no individual error was as large as twice the standard error of estimate. A tendency for narrow money supply equations to overpredict GNP during periods when $\mathrm{Q}$ is binding is consistent with the argument presented in the text. Analogous reduced form equations using bank credit instead of the narrow money supply tend, by contrast, to underpredict GNP during the period most directly influenced by tight money - though again, all individual errors were less than twice the standard error of estimate for the equation. A tendency for bank credit equations to underpredict GNP during periods when $\mathrm{Q}$ is binding is similarly consistent with the argument of the text. 
parative usefulness of "bank credit" and the money supply as "indicators" of the impact of monetary policy whenever the relationship between the two aggregates is influenced by the intervention of Regulation Q.

Two opposing positions have developed on these issues. At one pole is the view that, while Regulation Q may have sharp effects on relative money market rates and on the channeling of credit flows, it has little or no significance for the impact of monetary policy on aggregate demand. According to this view, the money supply is the only appropriate aggregate for measuring the impact of monetary policy. Fluctuations in the growth of bank credit within the context of a given expansion of money supply should be discounted as essentially irrelevant and misleading, reflecting "mere" disintermediation or reintermediation.

The opposing view is that Regulation $Q$ has been an essential part of restrictive monetary policy in recent years and that on several occasions, perhaps most notably in 1966, banks really began to tighten their lending policies only when they began to fear that application of $\mathrm{Q}$ ceilings might shut off CDs as a source of lendable funds. ${ }^{11}$ Proponents of Regulation $\mathrm{Q}$ as a policy tool have also argued on occasion that, through its use, a given degree of economic restraint can be achieved at lower interest rates than would be possible if that restraint were obtained through relatively slower growth of the money supply unaccompanied by an effective $Q$ ceiling. In part, this latter argument seems to have been based on little more than the superficial (and really irrelevant) observation that a lifting of the $\mathrm{Q}$ ceiling has on at least one or two conspicuous occasions been accompanied by a run-up in market rates on similar money market instruments. Some proponents of this view, however, seem to have in mind ideas similar to those presented above: If $Q$ ceilings are imposed, some borrowers will drop out of the credit market either because alternative open market channels are not available to them or because these channels are regarded as inferior. With these borrowers wholly or partially out of the credit market, "average" interest rates will fall at a given money supply (or, for that matter, at any given level of aggregate demand). ${ }^{12}$

11. A flavor of some of the elements underlying this view can be found in "Monetary Policy, Savings Competition and Commercial Bank Lending Behavior," remarks by Governor Andrew Brimmer at a luncheon held in Boston, July 18, 1966.

12. The notion of "average" rate behavior does raise an index number problem since it is clear that, even under the conditions assumed, rates in some markets could rise. This might occur, for example, if the distribution among different financial instruments 
While some opponents of Regulation Q would rely on the narrow money supply alone as their indicator, the Regulation $\mathrm{Q}$ adherents seem never to have embraced the opposite extreme position that bank credit alone is the correct measure of the tightness or ease of monetary policy. In any case, the only position compatible with the analysis presented here clearly must be somewhere in the middle. To argue that the effects of Regulation $Q$ are irrelevant and that only the behavior of the money supply need be consulted to gauge the impact of policy is to assume that the financial system is perfectly elastic, that is, all borrowers can find alternative nonbank credit channels that will be equally acceptable in terms of cost, convenience, liquidity, and so on. Only in such a case would the level of aggregate demand be totally unaffected by the imposition (or relaxation) of bank credit controls via Regulation Q.

On the other hand, it is equally unacceptable to believe that the financial system has no elasticity-a view to which the proponents of Regulation Q have at times come perilously close. On the whole, the unwillingness of the Federal Open Market Committee to embrace exclusively either the money supply or bank credit, as evidenced in its 1970 published reports, seems justified.

\section{SUMMARY}

Direct quantative controls over total bank credit seem to have little to recommend them in the U.S. setting, even from a relatively narrow technical point of view. As noted at the outset, such quantitative restrictions are not needed to achieve any given degree of general monetary restraint, since more conventional policy instruments, such as open market operations, appear sufficient for that purpose. To be sure, such controls could be used to reduce the volume of bank credit associated with any given money supply. Such a restriction can be expected to have various effects on credit flows, on interest rates, and on the level and composition of aggregate demand. However, substantially the same effects can be achieved with existing devices, such as Regulation $\mathrm{Q}$, that influence the volume of bank credit relative to any given money supply by discouraging or prohibiting the issue of nondemand deposit, interest-earning bank liabilities.

of the reinvestment demand of former $\mathrm{CD}$ holders failed to match the distribution of supplies of debt by former bank borrowers. 
Perhaps, as noted earlier, given results could be achieved more quickly and with more precision through controls over total bank credit in the form of quantitative quotas than through more conventional tools. It seems likely, however, that these "advantages" would prove of dubious value in practice. Thus, the speed with which any given degree of monetary stringency can be achieved is likely to be constrained more by the need to avoid abrupt and wrenching changes in financial market conditions than by any deficiency of existing monetary tools. The need to implement a policy of restraint in a reasonably gradual way would be as much a factor in the implementation of quantitative controls as it is with respect to existing means of producing monetary restraint. After all, existing devices such as reserve requirements and Regulation $\mathrm{Q}$ could, in principle, be used to produce sudden and drastic reductions in the money supply or bank credit, or both, in the unlikely event such changes were desired.

Perhaps quantitative controls over total bank credit would indeed speed the effect of a restrictive monetary policy in reducing the availability of bank loans to business. A similar quickening in the rate at which banks begin to tighten business lending policies in a period of tight money can, however, be achieved through the judicious use of Regulation Q, or through the use of specific controls over bank lending to business discussed in the next section.

The argument that quantitative controls would operate with more precision than existing techniques also does not seem very weighty. As long as the precise impact of any given degree of monetary restraint (however measured) on the economy is as uncertain as it is at present, the importance of pinpoint precision in controlling bank credit is very much open to question. Existing techniques are adequate to achieve broadly defined goals. Probably this is sufficient.

On balance, the main legitimate interest in quantitative credit controls seems to lie in their possible allocative effects. These are considered in more detail in the next two sections, which deal with controls over specific types of credit.

\section{Effects of Quantitative Controls on Specific Components of Bank Credit}

"Controls" over the composition of bank earning assets have probably been advocated more frequently than controls over the total. Recently, for example, there have been some proposals to influence the composition of 
bank assets indirectly through differential reserve requirement ratios on various categories of earning assets. Presumably the aim of controls over particular components of total bank credit would be to influence its distribution so as ultimately to reallocate resources. It is possible, for example, to imagine controls over business lending by banks as a way of quickly influencing a sector often thought to be the last to feel the effects of a general monetary tightening. Thus a given slowdown in the monetary growth rate coupled with controls over business loans might achieve a given degree of restraint over aggregate demand in a more balanced way, with less of the burden falling on housing, for example, than would be true given the same overall monetary slowdown but without specific controls over business loans.

For purposes of the analysis that follows, it is assumed that separate and individual quantitative restrictions are imposed on commercial and industrial loans, on loans to sales finance companies, and on consumer loans -again without altering the money supply target. These categories, which relate most directly to business and consumer spending, seem to be the most likely objects of controls. Mortgage finance and state and local government credit, as the most plausible intended beneficiaries of credit reallocation, are hardly likely themselves to be candidates for controls. Nor do bank purchases of federal government securities seem a likely target for controls. No specific assumption is made about total bank credit. Quite conceivably, total bank credit might decline as a result of controls on specific bank lending outlets, even with a given money supply. This would occur if the limitations on certain types of bank lending opportunities were to cause the banks to cut back time deposits or other nondemand deposit liabilities.

For convenience, commercial and industrial borrowers are assumed to fall into two classes: (a) prime borrowers, who have direct access to the capital markets, and (b) nonprime borrowers, who do not have the option of selling securities (such as bonds or commercial paper) on the open market. Nonprime borrowers, therefore, have as alternatives to bank borrowing only current saving, trade credit from prime borrowers with whom they do business, some minor specialized lending sources such as commercial factors, and sales of holdings of outstanding financial assets, such as Treasury bills.

It is to be expected, of course, that consumption outlays and business spending, the particular demand sectors directly affected by controls, will 
be depressed by them. The reasons are those just given for believing that aggregate demand will decline in response to a reduction in total bank credit. While both consumer and business borrowers do have alternative sources of funds, these alternatives will not represent perfect substitutes for the bank credit no longer available. The general process is the same whether the banks cut back business and consumer lending solely by nonprice rationing or solely by raising loan rates high enough to choke off demand by the desired amount. The pervasive fact of nonprice rationing in bank lending, however, will surely influence the distribution of loan reductions between business and consumer borrowers and between large and small business borrowers.

Assuming controls on commercial and industrial loans are framed in terms of the total of such loans, nonprime commercial and industrial borrowers would probably suffer the largest proportional cutback. In reaction, they would make use of the financing alternatives noted earlier or dip into their own liquid assets, but there would also be at least some cutback in physical investment in inventories and in plant and equipment.

Prime borrowers would also suffer some cutbacks in bank loans, though they probably would be proportionally smaller. These businesses have all the resources available to nonprime borrowers except that they are net suppliers, as a group, of trade credit. Under the assumed circumstances they might well be increasing rather than decreasing the amount of trade credit they supply. Presumably the volume of flotations of bonds and commercial paper would rise, not only to compensate for the reduced bank loans of prime borrowers but also to provide additional trade credit to nonprime business customers. In the limit, however, at least some reduction in physical investment by the prime commercial and industrial borrowers must be assumed.

Sales finance companies could offset reduced bank loans through increased sales of their own commercial paper and of other instruments. Nevertheless, there would be at least some reduction in their lending to consumers. Consumers would, indeed, suffer reductions in credit both from sales finance companies and from banks. They would respond by selling financial assets, such as holdings of U.S. government securities, and by reducing rates of noncontractual financial investment, such as flows into savings institutions. They could increase their use of mortgage and trade credit to some extent, but they would also curtail somewhat their spending, especially on consumer durables. 


\section{EFFECTS ON THE LEVEL AND COMPOSITION}

OF AGGREGATE DEMAND

In contrast to the case of controls on total bank credit, there does not seem to be any general presumption about the direction of influence of controls over particular components of bank credit on the level of aggregate demand or on the average level of interest rates. In one limiting case, it is possible to imagine a structure of relative interest rates such that an enforced cutback in business and consumer loans would lead the commercial banks to a 100 percent matching cutback in CDs and similar interest-bearing liabilities. This would be most likely to occur if business and consumer loans were the only assets sufficiently profitable to justify the marketing by these banks of CDs and other interest-bearing liabilities at the existing interest rates. In this case, a cutback of opportunities to lend to business and consumers would leave no profitable uses for $\mathrm{CD}$ and similar money. Consequently, instead of using the lending power diverted from business and consumer loans to increase credit extended to other borrowers, banks would repay maturing interest-bearing liabilities. In this extreme case, the analysis would follow exactly the line developed in the previous section in connection with controls on total bank creditexcept that the credit cutback would clearly be concentrated entirely in the areas of business and consumer lending under the present assumption, rather than being more generally diffused through the banking system's portfolio of assets. Again as in the limitation on total bank credit, the strong presumption here is that aggregate demand would fall.

Once one moves away from the assumption that the cutback in bank credit to the controlled categories is fully offset by a decline in interestbearing bank liabilities, however, the effects on aggregate demand become indeterminate. Thus suppose, instead, that banks forced to cut back on business and consumer lending by a control program do divert some or all of these funds into other, unregulated lending outlets, such as mortgages and tax-exempt and federal securities. In this case, the banking system's demand schedule for federal, state, and local securities, and for mortgages, would shift out to the right. Unless this outward shift were fully offset by a leftward shift in the demand for these assets by the nonbank public in reaction to reduced business and consumer loans-certainly an extreme 
and unlikely possibility ${ }^{13}$ - then rates on one or more of these types of assets will fall at the initial level and sectoral distribution of aggregate demand. Some shifts in the composition of output can, therefore, be expected in this case, with declines in consumption and business spending being partially or wholly offset by rises in spending by state and local governments or for residential construction. Whether such rises prove to be less than offsetting, just offsetting, or more than offsetting depends in part on the relative interest elasticities of demand of the various sectors.

Imagine a situation, for example, in which only business loans were subject to quantitative ceilings. Assume that banks offset declines in their holdings of such loans entirely through increased holdings of mortgages. Suppose further that the demand for housing is more sensitive to rates and to "credit availability" (in some sense) than is business investment demand. There will be an initial excess supply of business paper at the initial configuration of interest rates matched by an initial excess demand for mortgages. Bond rates, for example, will rise and mortgage rates will fall, increasing aggregate demand owing to the assumed greater sensitivity of housing to interest rates.

Thus the theoretical range of possible effects of controls over specific components of bank credit runs all the way from reduced to augmented aggregate demand. What course would actually develop clearly depends on a large number of elasticities. Without firm knowledge of these, one can only attempt a judgment of the probable outcome.

The history of recent periods of tight money suggests that, confronted with a limitation of business and consumer loan outlets, large-city banks, at least, would probably reduce outstanding interest-bearing liabilities on balance rather than divert most of the available funds to other outlets. First, these other outlets are unlikely to be very profitable, given the very high costs of, for example, Eurodollars and the probable high costs (in the absence of $\mathrm{Q}$ ceilings) of CDs. The restricted outlets, by contrast, have quite high yields. Consumer loan rates are relatively high and loans to long-standing business customers with substantial deposit balances are also likely to be quite profitable - at least from a long-run view. Moreover, the maturity structure of alternative investment outlets, such as mortgages and tax-exempt bonds, is poorly matched to relatively short-dated CDs and Eurodollar loans. Thus on grounds of both profitability and liquidity, it seems plausible that large-city banks, at least, would use a substantial

13. It rules out any effect of loan restriction on business and consumer demands for goods and services. 
part of the funds released by the curtailment of business and consumer loans to repay interest-bearing liabilities rather than redirecting these funds to other, unrestricted loan and investment categories. Smaller banks, to be sure, may not have large amounts of high-cost liabilities outstanding and so might use a larger fraction of the funds no longer tied up in business and consumer loans for reinvestment in other investment outlets such as mortgages. On balance, however, a reasonable guess is that controls on business and consumer borrowing would tend to depress credit to, and spending in, these sectors, with only a partially offsetting increase in credit flows to other sectors. If this is true, such controls would probably tend to depress aggregate demand over and above the restrictive effects of whatever slowdown in the monetary growth rate was being pursued (and would thus probably call for some alteration in this growth rate).

There is a more fundamental point, however: Whether banks respond to restrictions on business lending mainly by increasing lending to other sectors or mainly by repaying expensive interest-bearing liabilities, the restrictive controls on business and consumer spending would tend to depress these particular sectors for any given level of aggregate demand. To put it slightly differently, the slowdown in the growth of the money supply needed to achieve a given slowdown in aggregate demand might be greater or less with selective controls on bank credit components than without such controls. In either case, however, the imposition of controls would mean a relatively larger slowdown in the sector subject to controls and a relatively smaller slowdown in the uncontrolled sectors. Consequently, such controls could be used to encourage a relatively stronger performance by such sectors as housing and state and local government during a period of monetary restriction.

As a means of making business spending bear relatively more, and housing relatively less, of the brunt of tight money, quantitative controls on bank loans to business have both advantages and disadvantages in terms of economic issues alone, leaving aside the many important equity and procedural questions. In general, there appear to be two basically different ways of influencing the sectoral distribution of credit flows during tight money periods. One method concentrates on reducing the sensitivity to tight money of credit flows to favored sectors. This method is essentially the approach that is now being used with respect to housing through direct federal lending, through lending to private intermediaries specializing in mortgage finance, and through the provision of federal guarantees for mortgage instruments. The opposite approach is to inhibit flows of funds 
to sectors that are not favored, as would be the case with controls on bank lending to business. Since the effect of the first approach is to reduce the overall sensitivity of aggregate demand to interest rates and credit availability, it requires a relatively high level of interest rates (a relatively low rate of monetary growth) to achieve any given slowdown in demand. The advantage of the second approach, if advantage it be, is that it tends to lower the level of interest rates associated with any slowdown in aggregate demand.

A ceiling on the interest rate payable on large CDs shares some of the allocative and interest rate features of direct controls on business loans to the extent that in a tight money period, business loans suffer most when banks are unable to raise marginal funds through marketing CDs. Taking note of the 1970 suspension of ceilings on short-dated, large CDs, some capital market observers have recently suggested that if ceiling rates on large CDs are not used in some future period of monetary restraint, alternative and more direct controls over business lending by banks might have to be imposed to prevent housing from bearing a still larger share of the burden in restraining aggregate demand. ${ }^{14}$

While devices that tend to restrain bank lending to business may, from some points of view, have beneficial effects on the allocation of credit, they

14. See Albert Wojnilower, “The Environment of the 1970's: Can Capital Market Controls be Avoided?" (speech delivered to the National Industrial Conference Board, New York, January 14, 1971; processed); and Henry Kaufman, "Discipline and Stimulation in the 1971 Credit Markets" (speech delivered before the Sixth Annual Financial Conference of the National Industrial Conference Board, February 17, 1971; processed). Wojnilower argues that "we must expect ... that next time around banks will be made subject to asset reserve requirements-that they will be required to distribute their funds and credit lines in specified proportions among particular assets. . . . The banks who campaigned so ardently and arduously for the abolition of Regulation $Q$ may find that they have made a bad bargain; while free to compete for funds, they may be much more restricted in how they may use . . them." Similarly, Kaufman states that "there are strong expectations that the monetary authorities will not use the $\mathrm{Q}$ ceiling as a disciplinary measure the next time restraint is required. . . . How the banks will employ these additional funds will have far reaching implications. . . . If the commercial banks do not enlarge their role in the mortgage market voluntarily, the consequences are likely to be ... selective credit measures during the next period of restraint."

Governor Andrew Brimmer of the Federal Reserve Board has suggested differential reserve requirements on various categories of bank loans as a suitable selective credit device; see, for example, "The Banking Structure and Monetary Management" (a talk to the San Francisco Bond Club, April 1, 1970; processed), and Statement before the Subcommittee on Financial Institutions of the Senate Committee on Banking, Housing and Urban Affairs, 92 Cong. 1 sess. (1971), April 7, 1971. 
may have different, and adverse, implications for other aspects of the allocation problem. In particular, small businesses are likely to bear proportionally the larger part of any overall reduction of bank lending to business. Small businesses are, moreover, far more dependent on bank lending than are large businesses. Consequently, programs restricting business borrowing may aid one set of vulnerable borrowers, namely prospective homeowners, largely at the expense of a different set of vulnerable borrowers, the small businessmen. The next section analyzes credit controls aimed directly at large business borrowers through controls over corporate bond issues.

\section{Effects of Quantitative Restraints on Corporate Security Issues}

Without attempting to deal with the complex practical issues that would arise in controlling corporate bond issues, one can imagine a central registration bureau-a sort of "capital issues committee"- to which all potential issuers of corporate long-term debt, whether it is to be publicly sold or privately placed, would have to apply. (As before, the level-or rate of growth-of the money supply is assumed to be unchanged.) The agency might have control both over the amount of securities to be sold and over the timing of the offering. It might even adopt a system of priorities consciously designed to discriminate in favor of certain categories of borrowers and against others. For present purposes, however, the main point is simply that the agency operates so as to reduce the aggregate volume of offerings in the market below what it otherwise would be. Of course, the volume of bonds sold could also be restricted by rationing buyers rather than by rationing sellers. However, this approach would seem to be much more complex administratively. Moreover, it would tend to raise bond interest rates above their free market equilibrium level rather than to lower them, as would the type of capital issues control envisioned here.

By assumption, only prime business borrowers can float bonds and therefore only they are directly affected by the capital issues control. They can offset part of their loss of funds by reducing trade credit extended to nonprime business. For nonfinancial business as a whole, however, the only possible offsets are (1) increased bank loans, (2) increased sales of commercial paper, (3) sales of financial assets such as Treasury bills, and (4) reduced inventory and fixed investment. Again, there is every reason to believe that a cut in capital spending would represent part of the solution. 
Even at unchanged interest rates, increased bank loans are not a perfect substitute for bond sales because of their much shorter maturity and therefore poorer balance sheet or liquidity properties. Similarly, increased issues of commercial paper or sales of short-dated U.S. government securities by businesses needing funds are highly imperfect substitutes for issues of corporate bonds. These alternatives, even when feasible in sufficient volume, would involve a deterioration in business balance sheet positions. Finally, as far as the nonprime business borrowers are concerned, banks will probably be unwilling to offset fully with new bank loans the loss of trade credit formerly obtained from prime borrowers. The upshot of these considerations is the commonsense conclusion that business spending will in fact be curtailed to some degree as a result of the restriction of corporate bond sales.

To the extent that reduced corporate bond issues are in fact offset by reductions in capital spending, rather than by the adoption of alternative modes of finance, the net demand for funds by business on the financial markets at the initial set of interest rates will be reduced. To the same extent, the net supply of credit to other nonfinancial sectors at the initial set of interest rates will rise. Corporations, to be sure, would be sellers of the instruments of these other sectors, as already noted. Moreover, since total bank credit is unchanged, ${ }^{15}$ and since banks will increase their volume of business loans, they will also have to be net sellers in order to make room for these additional business loans. However, consolidated net sales of nonbusiness paper by business and by the banks will equal the originally legislated cutback in corporate sales of corporate securities less the reduction in business investment spending. In other words, individuals and nonbank financial intermediaries will still have a net supply of funds even after absorbing bank and business sales of other instruments.

This situation may be clarified by a numerical example, showing changes in assets and liabilities of nonfinancial businesses and of banks (Illustration 1). In this case, the effect of the capital issues control is assumed to reduce by 10 the net flow of corporate financing in the bond market. Corporations are assumed to respond by increasing bank loans by 6 , by reducing their net

15. There is certainly no reason why total bank credit should fall. Quite conceivably it might rise if the additional business loan demand induced banks to sell additional CDs and other interest-bearing liabilities. Such a circumstance would, however, merely strengthen the conclusion that the supply of credit to other nonfinancial sectors would rise at the initial set of interest rates. 
acquisition of instruments of other nonbank sectors (for instance, Treasury bills) by 1 , and by cutting the level of capital investment by 3 . Since the level (or rate of change) of bank credit is assumed to be unaffected, the increased rate of acquisition of business loans by banks is matched by sales (or reduced rates of acquisition) of paper issued by other sectors. Thus the net supply of funds by the nonbank, nonbusiness sectors declines by 3 , even after allowing for the reduction in bank lending to these sectors; that is, 3 equals 10 (the reduction in corporate bond sales), less 1 (the sale of Treasury bills), less 6 (the reduction in bank credit extended to these other sectors).

\section{Illustration 1}

All nonfinancial business

\begin{tabular}{llll}
\hline$\Delta$ Investment & -3 & $\Delta$ Bond flotations & -10 \\
$\begin{array}{c}\Delta \text { Holdings of debt of } \\
\text { all other sectors }\end{array}$ & & $\Delta$ Bank loans & +6 \\
& -1 & & -4
\end{tabular}

Commercial banks

\begin{tabular}{lc}
\hline$\Delta$ Business loans & +6 \\
$\Delta$ Holdings of debt of \\
all other sectors & $\frac{-6}{0}$
\end{tabular}

Now since any reduction in corporate investment makes available a net supply of funds at existing rates to the other nonfinancial sectors, average rates on the instruments issued by these sectors should fall. Moreover, if spending is at all interest elastic in these sectors, the rise in outlays within them will at least partially offset the decline in spending in the business sector. ${ }^{16}$ Illustration 2 reflects the flow of funds accounts in a case where a

16. The argument can be put somewhat more precisely: To the extent that the reduction in bond sales by the business sector is offset by reductions in physical investment, the consolidated net financial investment of the other nonfinancial sectors and of the nonbank financial intermediaries must decline. This is the accounting truism shown in the illustration. Also as a matter of accounting, this decline in net financial investment by consumers (and others) must be offset either by increased investment in, say, housing or by a decline in current saving. The economic argument of the text is that given the initial, pre-controls values of income and interest rates, consumers and nonbank financial intermediaries will bid down yields on, for example, mortgages, stimulating investment in housing. The ultimate equilibrium position of aggregate demand depends on 
fall in business spending of the amount assumed in Illustration 1 turns out to be just offset by a rise in outlays for residential construction. (The numbers for the business and banking sectors in Illustration 2 are the same as those in Illustration 1, but this time more detail is presented both for these and the remaining sectors.)

\section{Illustration 2}

All nonfinancial business

\begin{tabular}{llll}
\hline$\Delta$ Investment & -3 & $\Delta$ Bond flotations & -10 \\
$\Delta$ Governments & -1 & $\Delta$ Bank loans & +6 \\
& -4 & & -4
\end{tabular}

Consumers

\begin{tabular}{llll}
\hline$\Delta$ Corporate bonds & -5 & $\Delta$ Mortgages & +3 \\
$\Delta$ Governments & +4 & & \\
$\Delta$ Housing & +3 & & \\
$\Delta$ Nonbank financial & & & \\
$\quad$ intermediaries & & & \\
$\quad$ liabilities & $\frac{+1}{+3}$ & & +3
\end{tabular}

Commercial banks

\begin{tabular}{lll}
\hline$\Delta$ Business loans & +6 & \\
$\Delta$ Governments & -4 & \\
$\Delta$ Mortgages & -2 & -
\end{tabular}

Nonbank financial intermediaries

\begin{tabular}{llll}
\hline$\Delta$ Corporate bonds & -5 & $\Delta$ Liabilities & +1 \\
$\Delta$ Governments & +1 & & \\
$\Delta$ Mortgages & +5 & & -1
\end{tabular}

how responsive housing proves to be to the decline in interest costs. If the resulting stimulus to housing just exactly offsets the decline in business investment (as in Illustration 2), equilibrium GNP, saving, and total investment are unchanged. If, however, the demand for housing (and /or other nonbusiness investment items) is completely unresponsive to declines in yields on mortgage and other instruments, GNP must decline until the (induced) decline in nonbusiness saving just equals the initial decline in business investment attributable to the capital issues control. This extreme possibility can be rejected as highly unrealistic, however. 
To what extent would a capital issues control deter business spending, and therefore free funds for spending in other sectors? In practice, a main determinant might be the expected duration of the embargo on corporate bond flotations. The chief factor deterring business from simply replacing reduced sales of bonds with increased bank borrowings (or increased sales of Treasury bills and other short-term financial assets) would probably prove to be the adverse effects of such substitutions on the maturity structure of business liabilities. Obviously, firms will not undertake long-lived investment projects if they expect long-term financing to be indefinitely unavailable. On the other hand, if they expect the capital issues control to last only a few months, they would probably be willing to increase their bank borrowings as a temporary substitute for sales of long-term bonds. Indeed, a control program announced in advance to last for only a few months might well have only very small effects on business investment.

Since business spending undoubtedly would be restricted to some degree by controls over corporate bond issues, this measure has much the same allocational impact (and appeal) as controls over bank lending to business. A given degree of restraint on aggregate demand, engineered by general monetary and fiscal policies, would be associated with a relatively larger impact on business spending and a relatively smaller impact on housing and other sectors. Relative to controls over bank lending to businesses, moreover, it has the appeal (to some) of falling directly on large business and therefore avoiding the discrimination against small business that seems to be inherent in restrictions on bank lending to business. No doubt there is something in this-but only something. Small businesses would be restricted by rationing of bond issues even though they themselves do not utilize this form of financing; for corporate business would respond to the restraint in part by reducing trade credit to smaller firms that would, in turn, be forced to rely more heavily on bank loans. At the same time, moreover, the larger firms would also be turning to the banks for short-term accommodation while waiting out the embargo on bond sales. Thus there would be less bank credit available for small firms at the very time when they became more dependent on it.

\section{Summary and Conclusions}

One broad conclusion emerges from the preceding analysis of quantitative credit controls. Even in the context of a given money supply policy, 
such controls can, for better or for worse, exert an influence over both the level and composition of aggregate demand. The reason is that disruption of normal financial channels will, at least in the short run, be adjusted to in part by reductions in outlays for goods and services in the sectors affected. ${ }^{17}$ Unless the controls over financing are extremely comprehensive, to be sure, alternative sources of funds to finance real outlays will be available and will be used. These alternative sources, however, will be regarded as imperfect substitutes on the part of the potential borrowers, because of relatively undesirable effects on balance sheet structure, inferior convenience or higher transactions costs, relatively higher interest rates, and more stringent credit rationing.

While one side of the story is that alternatives are never perfect and that, as a result, some net effects on spending will take place, the other side is that alternatives do exist and that in a financial system as flexible and sophisticated as ours they are likely to bear readily a substantial part of the burden of adjustment to the imposition of controls on particular credit channels. Moreover, the ability of the financial markets to provide substitutes for any credit channel that is subjected to control undoubtedly increases with time, as firms seek and find new alternatives, establish new contacts, create new instruments, overcome set-up costs, and so on.

Quantitative controls over total bank credit could in principle be used to hold it below the level that would otherwise emerge in conjunction with some targeted money supply. Given such controls, the banks would find an incentive to reduce other liabilities, mainly CDs and Eurodollar borrowings. Reflecting the financial system's inability to provide perfect substitutes for restricted channels of credit flows, at least in the short run, there would be some cuts in spending and therefore at least some tendency for aggregate demand to fall.

What is true of the effects of direct, quantitative controls over total bank credit, given the money supply, is also true of indirect controls through the application of such devices as Regulation $\mathrm{Q}$ to nondemand deposit liabilities. These devices also have the effect of retarding the growth of bank credit relative to what it would otherwise be for any given rate of growth

17. Of course, any device that influences relative interest rates, whether quantitative credit controls, a system of taxes and subsidies on interest rates paid on different kinds of financial instruments, or a system of differential asset reserve requirements for one or more types of financial intermediaries, will influence at least the composition of aggregate demand. 
in the money supply. Like direct controls on total bank credit, these devices disrupt normal credit channels and force borrowers to rely on more expensive and less convenient (perhaps even nonexistent) substitutes. Thus they also reduce spending by these borrowers, lowering aggregate demand. By rationing some credit demands out of the market, these devices, again like direct credit controls, may also tend to lower somewhat the general level of interest rates associated with any given overall degree of restraint on aggregate demand-although both direct credit controls and devices like Regulation Q could also conceivably tend to raise some interest rates.

As noted earlier, direct controls on total bank credit in the form of quantitative ceilings do not seem to have any significant technical advantages over the existing instruments of monetary control. Such ceilings do not appear to be needed to achieve any desired degree of general monetary restraint, given the power of more orthodox instruments. Moreover, they do not seem likely to speed the response of the economy to monetary restraint. The main limitation on the speed with which restraint can be achieved with existing tools appears to be the need to avoid overly abrupt adjustments in financial markets, not technical limitations inherent in the existing machinery. The allocational and interest rate effects that might be achieved with ceilings on total bank credit, given the money supply, can, if it seems desirable, generally be accomplished with Regulation Q and similar inhibitions on the issuance of interest-bearing bank liabilities.

Generally speaking, the main interest of credit controls seems to lie in their potential for altering the incidence, rather than the overall efficacy, of restrictive monetary policies. From this point of view, controls over particular components of bank credit appear far more relevant than controls over the total. Controls over bank credit components, especially business and consumer loans, could be expected to have depressing effects on these sectors. By expanding bank credit flows to other sectors, such controls could have stimulating effects there that might, in principle, offset or even outweigh their depressing effects on business and consumer spending. To be sure, banks might in practice react to curbs on business lending mainly by repaying interest-bearing liabilities rather than by expanding credit to other sectors. This possibility, however, does not invalidate the more general point that such controls would permit any given degree of overall restraint on total demand to be achieved with relatively more restraint on business spending and relatively less restraint on other sectors, including housing. Whether or not $\mathrm{Q}$ ceilings on consumer-type savings deposits at 
commercial banks and other savings institutions are, on balance, good for housing, ceilings on large CDs probably do have some beneficial effects for housing (and other sectors) much like those that might result from direct controls on bank lending to business.

A problem with direct controls on lending to business and, by implication, with Q ceilings on large CDs as well, is that they may hit hardest at the small businessman who is a relatively marginal borrower and who is relatively more dependent on bank lending as a source of funds. This problem suggests the possibility of a capital issues control as an alternative means of restricting business spending, since such a control would impinge directly only on large corporations that normally use bond financing as a means of obtaining funds. The ability of controls on capital issues to restrict business without hitting small business disproportionately should not be exaggerated, however. Withdrawal of trade credit by hard-pressed large firms would tend to force smaller business into the banks at the very time the larger firms are also turning to them for temporary accommodation.

Finally, as noted earlier, even if a given credit control can be shown to lead to a desirable resource reallocation, it does not necessarily follow that such a control should be adopted. One must always ask whether the same reallocation effects could be achieved better by other means and whether, in any case, the quantitative effects of the control are likely to be large enough to outweigh the inevitable administrative and other problems associated with it. 


\section{Comments and Discussion}

James Duesenberry: Most people agree that the present arrangements for influencing economic activity through monetary policy work through long and complex chains of interaction in the market. The whole thing is a kind of Rube Goldberg machine. Second, it is widely recognized that the quantitative effects of monetary policy are not precisely predictable, and that the time lags may be long and variable. Third, it is also generally agreed that monetary policy has significant and often undesirable side effects. Some of these are on resource allocation, particularly with respect to the housing sector. Others include the redistribution of wealth, threats to the solvency of financial institutions, and the danger of financial crisis that accompany a powerful dose of monetary restraint.

As a result, popular demand arises for some mechanism that will work more directly, more surely, more rapidly, and with less adverse side effects. Some devices have been developed to improve the mortgage market and to reduce the credit rationing to that sector during periods of tight money. However, people are looking for something that restricts competing sectors in addition to cushioning the impact on especially vulnerable sectors.

The Davis paper contributes to this exploration. It examines the question of whether stabilization efficiency could be increased or adverse side effects reduced by using a variety of different types of direct controls. I agree with Davis' general conclusions and I like his approach.

The basic principle underlying the analysis is its conception of the function of the banking system. Even with a constant money supply, as postulated in the paper, the banking system intermediates the supply of savings and the demand for credit through pooling, through specialized credit evaluation, through the use of its own capital, and through combining the credit system with the payments mechanism. The banking 
system offers liabilities that are more attractive to depositors at any given rate of interest than the liabilities of households, firms, and governments that obtain their credit from banks, thus reducing the cost of capital all around.

Suppose banks are prohibited from offering time deposits. Then the spending units that now sell their liabilities to banks would have to sell directly to the public or to other intermediaries. Large businesses that issue commercial paper presumably could develop fairly close substitutes for bank credit. They might experience some adverse price effect, but it would probably not be much. Small businesses, on the other hand, would find it much more difficult to finance themselves directly. They would have to go through factors or equipment finance companies, or use trade credits. They would find the terms of credit much less favorable. There would undoubtedly be some tendency for them to reduce expenditures. In short, if the banking system is performing a function, the elimination of the system, or even just its time deposits (so the money supply can be held constant), must raise the cost of capital to those dependent on bank credit. Analogously, if we ban vegetable wholesalers and they perform a valuable function, we would expect to find higher costs of vegetables at retail and lower returns to vegetable farmers, especially small farmers.

Everything taken together, the net restraint would be much smaller than the gross restraint on bank lending. The mortgage market would ease as funds previously held in consumer time deposits flowed into the savings and loan associations. However, there would be some net restrictive effect in addition to what would be obtained by control of the money supply. Average interest rates might be lower and the allocation of credit to the mortgage and municipal bond markets might be improved.

There are, however, some costs to pay for such a policy, or the more relevant policy of a partial restraint on bank credit. One, of course, is the heavy impact on small businesses. The regulations could be fixed to give them special protection, but that is just the way that nice, simple regulations get very complicated and cumbersome. Second, risk and uncertainty would be increased even for large businesses, because the commercial paper market is not as dependable as bank credit lines.

If the regulations became a normal instrument of monetary restraint, the financial system would adapt to them. Large businesses would be induced to build up their liquidity in periods of relaxation. The monetary authority would face a dilemma in slack times: Low interest rates and easy credit 
conditions that would be desired to stimulate the economy would permit a buildup in liquidity, which in turn would delay and impair the effectiveness of restrictive monetary policies during a subsequent boom. In responding to the dilemma, the central bank would be forced either to keep money tighter than would be desirable in slack times or to settle for less effective restraint in boom times. For these reasons, quantitative restrictions must not be allowed to become anticipated; they must "sneak up" on the market quickly and unexpectedly to be effective. The banking system wais not completely surprised in 1969 after its experiences of 1966, and it evaded fairly effectively the impact of Regulation Q during most of 1969. When the control finally began to have some effect, it came dangerously close to causing a real credit crisis. All of this argues that Regulation Q (and perhaps other restrictive regulations) ought to be available for emergency use, but should not be used normally in an ordinary peacetime expansion.

This leads me to the further conclusion that the regulation of business investment, either to stabilize economic activity or to shift resources to other sectors, should be applied directly. Monetary policy, in so far as it is directed toward the control of business investment, is a device for raising the cost of credit or rationing it. The cost of investment could be raised directly in a boom by putting a temporary tax on it-the reverse of the investment tax credit. The timing properties of a tax would not be particularly favorable either, but would be as good as those of a rise in the interest rate. In view of the defects of monetary policy in terms of lags and uncertainties, we ought to have more strings to our bow. There are some arguments for supplementary weapons to control business investment and an instrument of variable taxation might be useful.

David Fand: Davis analyzes three kinds of quantitative credit controls: (a) limits on total bank credit but not its composition, (b) limits on specific components of bank credit but not its total, (c) limits on specific users of credit. Davis suggests that direct control over total bank credit is analytically equivalent to indirect controls through Regulation $\mathrm{Q}$, and argues that it will have a net restrictive effect on aggregate demand and on interest rates. In contrast, he finds that specific quantitative controls on particular categories of bank credit and on particular users of credit may have a selective impact on particular categories of expenditure without necessarily affecting aggregate demand.

Quantitative credit controls are not needed to achieve a desired degree of 
monetary restraint, he concludes, since this restraint can be achieved readily by the conventional instruments. In particular, the effects of direct quantitative controls over total bank credit may also be accomplished with existing indirect controls, such as Regulation Q, that inhibit the issuance of interest-bearing bank liabilities.

The main appeal of direct controls on bank credit is their potential for altering the incidence rather than the efficacy of restrictive monetary policy. Accordingly, control over particular components of bank credit (business and consumer loans, for example) would seem to offer the possibility of achieving more restraint on business and consumer spending and thereby making available an expanded volume of bank credit for other sectors. But direct controls on lending to business, as well as indirect controls achieved through $\mathrm{Q}$ ceilings on large CDs, may hit hardest at the small businessman. From this point of view, a capital issues control may appeal as an alternative method of directly restricting the large corporations. But even so, it may hit small business indirectly. Finally, we must consider, as Davis suggests, whether the desired allocational effects outweigh the administrative problems inevitably associated with such controls.

The upshot of this analysis is that if the aim is a particular resource allocation in the real economy, credit controls over narrowly defined categories may be more effective than broadly defined controls. On the other hand, if credit controls are specified very precisely, they may also be easier to evade. It may, therefore, be difficult to achieve specific objectives of resource allocation by monetary or credit controls. The conventional monetary instruments do not lead directly to any particular flow of funds; and even direct or indirect controls suitable to engineer the desired credit flows may not bring about the desired pattern of real expenditures. There is one gap between the monetary instruments and the flow of funds in credit markets, and there is a second gap between the credit flows and the pattern of expenditures that emerges in the real economy.

Davis argues that controls (direct and indirect) over total bank credit will tend to lower interest rates and reduce aggregate demand, on the grounds that they may lower the IS but need not affect the LM curve, although he notes that the result may be indeterminate. Moreover, if we take account of the announcement effects of introducing controls on bank credit and other dynamic effects, it is even more difficult to say anything precise about their likely impact.

In analyzing whether a particular set of quantitative bank credit controls stimulates (depresses) aggregate demand, one might consider whether it 
accelerates (decelerates) the growth of $\mathrm{M}_{2}\left(\mathrm{M}_{1}\right.$ plus time deposits in commercial banks) and $\mathrm{M}_{3}$ ( $\mathrm{M}_{2}$ plus savings deposits in thrift intermediaries). The growth in $\mathrm{M}_{2}$ and $\mathrm{M}_{3}$ in the last few quarters has been exceedingly large, and one might suspect that a reduced-form expenditure equation using $\mathrm{M}_{1}$ would therefore make large underprediction errors in explaining GNP. Yet, the Andersen-Jordan (Federal Reserve Bank of St. Louis) expenditure equation using $\mathrm{M}_{1}$ seems to have projected the 1971 first quarter results reasonably well. One wonders why the $\mathrm{M}_{1}$ equation does not seriously underpredict the GNP in recent quarters. For one thing, the omission of interest rates would lead one to expect an overprediction, and perhaps that omission just offsets the omission of $\mathrm{M}_{2}$ and $\mathrm{M}_{3}$.

Davis' analysis does not make clear why the control of total bank credit should depress aggregate demand while controls over components of bank credit act more like selective controls. Why should we necessarily get aggregate demand effects when we control all of bank credit and not get such effects when we control several major components of bank credit? After all, bank credit is only one component of total credit.

It is difficult to specify at what point selective credit controls have important effects on aggregate demand. Accordingly, an alternative procedure is to assume that even controls on total bank credit do not necessarily affect aggregate demand-at least as a first approximation-and to analyze their impact on this basis.

But I do agree with Davis' argument that a quantitative difference may, after some point, bring about qualitatively different effects. Thus, suppose we steadily reduce the scope, and extent, of intermediation in the economy by placing controls on the intermediaries. This will raise interest rates, and a larger and larger money supply will be required to achieve a given GNP. As we interfere with intermediation by introducing an increasing array of selective controls, the cumulative effect could very well restrict aggregate demand. But we are still left to rationalize why control over total bank credit, in contrast to control over components of bank credit, achieves this critical mass at which selective controls begin to have pronounced effects on aggregate demand.

Lawrence Krause: Because short-term interest rates and monetary flows have joined financial markets so completely, direct controls are seen by many international economists as a device for restoring some independent, domestically oriented monetary policy. The Bank for International Settle- 
ments seems ready to recommend that countries institute direct controls on credit. Essentially the idea is that the growth in bank credit would be controlled so that the same degree of restraint could be obtained without the sharp rises in interest rates that draw interest-sensitive funds from abroad. Conversely, when monetary policy subsequently eases, rates would drop less sharply. Direct credit controls would thus narrow the variation in market interest rates.

Regulation $\mathrm{Q}$ works the wrong way in terms of these goals. It exaggerates the movement in international money flows. If there is monetary restraint at home, it causes more restraint abroad, and vice versa. Thus, international considerations would point to the need for controls on the asset side of the banking system. Yet, an analysis of how quickly U.S. financial institutions can replace bank loans with other types of instruments should make clear that this recommendation makes no sense for the United States. It would be another ineffective, unnecessary, active balance-ofpayments policy.

Richard Davis: I generally agree with Duesenberry's comments on the limitations of Regulation Q, as revealed by recent experience. However, it could be made more effective, if needed, by application to a broader range of liabilities than just CDs. The Federal Reserve can define more broadly what the regulation applies to and it should use that power.

In response to Fand's question about why control of total bank credit would be restrictive on aggregate demand, while partial control would not, I want to explain that I think the control over large segments would restrain demand, but I have to allow for the possibility that the diversion into other channels of bank credit would neutralize the aggregate impact.

Krause points out that the Bank for International Settlements is interested in direct controls. The impression I get from a number of countries that have invoked quantitative credit controls is that they feel this is the only way they can effectively regulate aggregate demand. This surely is not the case for the United States.

\section{General Discussion}

William Branson wondered why there was such concern about the cyclical impact of monetary policy on housing. In a sense, it seems appro- 
priate that homebuilding should be strongly affected by stabilization policy. Housing is an extremely durable good. Postponing construction of houses for a year and letting the housing stock get that much older imposes less disutility on consumers than postponing an equal output of less durable goods. Perhaps the real source of concern is the depressed long-run trend of housing, rather than its cyclical fluctuations. In particular we may judge that the tendency to rely on monetary policy for restraint and fiscal policy for stimulus has held down the long-run trend of homebuilding.

Several participants felt that the vulnerability of homebuilding to tight money was far greater than could be accounted for by the particular sensitivity to high interest rates that would be expected from long-lived assets. Factories may be as durable as homes, but they do not respond similarly. The imperfections of the mortgage market, its dependence on thrift inflows, and the extent of nonprice rationing in that market have to be part of the explanation, they contended.

Warren Smith felt that not enough emphasis had been placed on the differences in the purpose and function of the interest rate ceilings on small time deposits and the interest rate ceilings on large certificates of deposit. Paul Samuelson, Daniel Brill, and others agreed. Ceiling rates on small time deposits are not meant to intensify monetary restraint on business, but rather to protect the housing sector. In 1966, savings and loan associations were facing a major liquidity crisis, in part because banks could pay higher rates on time deposits than they could. The Federal Reserve did not have the legal authority until late 1966 to differentiate the interest rates paid by banks on small time deposits from those paid on large certificates of deposit. Since that has been remedied in part, Brill pointed out, there has not been the same intense concern that the banks would competitively drain away funds destined for housing. Alan Greenspan noted, however, that the regulations on small time deposits might not be equally effective in another period of tight money. Just before money eased in 1970, some large corporations had begun to think of creating money market instruments in small denominations that would appeal to small savers. Paul Samuelson was concerned about the regressive impact of the ceiling rate on small time deposits. The protection of homebuilding was achieved at the expense of small savers.

The impact of interest rate ceilings on large certificates of deposit was debated extensively. The interest rate on large CDs had been held down to restrict the funds available to large banks and to large businesses, but, it 
was generally agreed, most of the intended impact had been evaded. The banks tapped the Eurodollar market for funds and the large businesses turned to the commercial paper market. Perhaps, Regulation $Q$ on large CDs had made it somewhat more expensive and difficult for large businesses to borrow, but it had not reduced their investment much. It was questioned whether other interest rates had been held down somewhat as a result. There was some discussion of whether the controls might have been more effective if Eurodollar borrowings had been restricted, sacrificing the temporary balance-of-payments benefits.

Daniel Brill wondered whether the recent experience may have changed the elasticities of response in the financial market. For many industrial borrowers, the commercial paper market did not prove to be a satisfactory substitute for bank credit. And the Penn Central episode may have impaired it as a substitute device for a long time to come. Bank credit lines may look even more important as a result. Brill noted that certain other intermediaries, like finance companies, were far more dependent on bank lines of credit as an insurance device than on actual bank loans. Restraints on bank lending would not affect them as directly unless the credit lines were cut back.

Franco Modigliani felt that Regulation Q might have had some effect in the very short run because time was required to build up other sources of funds. Paul Samuelson said that quantitative controls and rationing devices produced incentives to create an ersatz banking system and ersatz money $-M_{1}$ and $M_{2}$ really change their meaning. Duesenberry suggested that the issue was primarily how rapidly and how readily substitutes for $\mathbf{M}_{2}$ are created. As one banking system is extinguished, another develops. In the intervening period of time, the regulations are effective, however. The question is whether that finite interval is long enough to make the effort worthwhile.

Charles Bischoff supported Duesenberry's preferences for direct measures, such as a tax to affect business fixed investment. He felt that the lenient treatment of outstanding orders when the investment tax credit was restored in 1967 had created a credibility gap. If businessmen expect that all will be forgiven when a temporary investment tax is ended, they will not curb orders for capital goods. Bischoff also suggested that, if a capital issues committee is worthy of serious consideration, one might as well have a capital expenditures committee that would focus on the real target directly. 